\title{
Population Genetic Analysis of Puccinia striiformis f. sp. tritici Suggests Two Distinct Populations in Tibet and the Other Regions of China
}

\author{
Xiaoping Hu and Lijie Ma, State Key Laboratory of Crop Stress Biology for Arid Areas, College of Plant Protection, Northwest A\&F Uni- \\ versity, Yangling, Shaanxi 712100, China; Taiguo Liu, State Key Laboratory for the Biology of Plant Diseases and Insect Pests, Institute of \\ Plant Protection, Chinese Academy of Agricultural Science, Beijing 100193, China; Conghao Wang, College of Plant Protection, Northwest \\ A\&F University, Yangling, Shaanxi 712100, China; Yuelin Peng, Tibet Agricultural and Animal Husbandry College, Linzhi 860000, China; \\ Qiong Pu, Tibet Autonomous Region Agricultural Technology Extension and Service Center, Lhasa 850000, Tibet; and Xiangming Xu, \\ NIAB East Malling Research, New Road, East Malling, ME19 6BJ, Kent, U.K.
}

\begin{abstract}
Wheat stripe rust, caused by Puccinia striiformis f. sp. tritici (Pst), is an important disease on wheat, seriously threatening wheat production worldwide. China is one of the largest stripe rust epidemic regions in the world. The pathogen sexual reproduction and migration routes between Tibet and the other regions in China are still unknown. In this study, we obtained 961 Pst isolates from 1,391 wheat leaf samples from Gansu (277), Shaanxi (253), Sichuan (172), and Tibet (259), comprising 13 natural populations, and genotyped them with simple sequence repeat (SSR) markers. The isolates can be divided into two distinct clusters based on DAPC and STRUCTURE analyses. The genetic diversity of Longnan

(in Gansu) and Yibin (in Sichuan) populations was the highest and lowest among the 13 populations, respectively. The hypothesis of multilocus linkage disequilibrium was rejected for the populations from Linzhi in the Himalayan, Longnan, Hanzhong, Guangyuan, Mianyang, Liangshan, and Chendu in the south Qinling Mountains at the level of $P=0.01$, which indicated significant linkage among markers in these populations. Populations in the other regions had extensive gene exchange $\left(N_{m}>4\right)$; little gene exchange was found between Tibet and the other regions $\left(N_{m}<1\right)$ The results suggest that the Tibet epidemic region of $P$ st is highly differentiated from the other epidemic regions in China.
\end{abstract}

Wheat stripe rust, caused by the basidiomycete fungus Puccinia striiformis Westend. f. sp. tritici Eriks. (Pst), is one of the most damaging diseases on wheat (Triticum aestivum) worldwide (Chen 2005; Hovmøller et al. 2010, 2011). It is a globally distributed and winddispersed pandemic disease. Urediniospores of Pst can be dispersed by atmospheric circulation up to $1,000 \mathrm{~km}$, leading to rust spreading across large areas within a single growing season (Zeng and Luo 2006). Pst is a plant pathogen that evolves rapidly and can cause serious yield losses. In China, wheat stripe rust caused yield losses of $6.00,3.20,2.65$, and 1.40 million metric tons when severe epidemics occurred in 1950, 1964, 1990, and 2002, respectively (Li and Zeng 2002; Wan et al. 2004).

The epidemics of wheat stripe rust in China can be subdivided into three epidemiological regions based on geography, climatic conditions, agronomy, Pst race composition, and epidemic characteristics (Hu et al. 2012; Li and Zeng 2002; Zeng and Luo 2006): the main epidemiological region (geographic ranges of 87 to $135^{\circ} \mathrm{E}$ and 22 to $53^{\circ} \mathrm{N}$, covering Gansu, Shaanxi, Sichuan, Hubei, Henan, Yunnan, and Guizhou provinces), the Xinjiang epidemiological region, and the Tibet epidemiological region (Fig. S1). Dispersal of Pst inoculum within the main epidemiological region has been studied based on climatic conditions (Wang et al. 2010a) and fungal population structure at the molecular level (Chen 2008; Lu et al. 2011; Shan et al. 1998). However, fungal population genetic structure in the Tibet epidemiological region and its genetic relationship with the other epidemic regions are still unknown.

Several studies revealed an overall clonal population structure of Pst with low genetic diversity worldwide (Chen et al. 1993; Cheng

Corresponding author: X. Hu; E-mail: xphu@nwsuaf.edu.cn

X. P. Hu, L. J. Ma, and T. G. Liu contributed equally to this study.

*The $\boldsymbol{e}$-Xtra logo stands for "electronic extra" and indicates that three supplementary figures are available online.

Accepted for publication 12 October 2016.

() 2017 The American Phytopathological Society and Chen 2014; Enjalbert et al. 2005; Hovmøller et al. 2002; Wellings 2007), except in China, Nepal, and Pakistan (Ali et al. 2014a,b; Duan et al. 2010; Mboup et al. 2009; Zhao et al. 2013). However, Duan et al. (2010) demonstrated that Chinese Pst isolates from Gansu Province exhibited high genetic diversity and evidence of recombination. A very recent worldwide population genetic structure analysis of $P$ st also indicated a high regional heterogeneity in levels of recombination, with clear signatures of recombination in the Himalayan and near-Himalayan regions (Ali et al. 2014b). However, the sexual reproduction of Pst in China remains unknown although Zhao et al. (2013) demonstrated that Pst can infect some Berberis spp. through greenhouse work, which may lead to sexual recombination on Berberis spp.

The information on factors affecting fungal population genetic structure is critical if we are to develop disease management strategies based on the knowledge of the patterns of pathogen migration among regions. This paper reports a study comparing Pst populations from Tibet and other regions (excluding the Xingjiang region) using SSR markers to infer Pst population biology, migration routes, and potential sexual reproduction.

\section{Materials and Methods}

Sampling Pst-infected leaves and multiplying urediniospores. A total of 1,391 Pst samples were randomly collected from adult plants of 96 fields in Gansu (347), Sichuan (349), Shaanxi (200), and Tibet (495) provinces in 2009 and 2010. These sampling areas were classified into 13 geographical regions (Table 1). Leaves with fresh uredinia pustules but without signs of other pathogens were sampled. Leaf surfaces were gently dried with a piece of absorbent paper, enclosed in an envelope, and kept inside a desiccator at room temperature for not more than 7 days before inoculum multiplication. To produce fresh urediniospores on those sampled leaves, the leaves were washed with water, placed on water-soaked tissue paper in petri dishes, and then incubated in the dark for $12 \mathrm{~h}$ at 10 to $13^{\circ} \mathrm{C}$. Urediniospores were then collected to inoculate seedlings of $\mathrm{cv}$. Mingxian 169 (a cultivar highly susceptible to all known races of Pst identified in China) for multiplication.

Ten seeds were sowed in a $10 \mathrm{~cm}$ diameter pot, containing cow dung compost and soil $(1: 2, \mathrm{v} / \mathrm{v})$. When the first leaf of seedlings had fully expanded (approx. 8 to 10 days after sowing), a single urediniospore from a freshly sporulating lesion on the sampled leaf was 
picked up with a sterile insect needle under a microscope (Olympus BX51, Japan) at 200 $\times$ and transferred onto a leaf. A single seedling received a single urediniospore. Immediately after inoculation, seedlings were kept in a dew chamber at $10^{\circ} \mathrm{C}$ for $24 \mathrm{~h}$ and then placed on benches in a glasshouse compartment with the temperature set to 16 : $14^{\circ} \mathrm{C}$ (day/night) and a photoperiod of 10:14 h (day/night). When a lesion became visible on each inoculated leaf, seedlings inoculated with spores from the same lesion on each sampled leaf were separated from other seedlings with a plastic cylinder to prevent cross contamination. Fresh urediniospores produced on these inoculated seedlings were collected separately, vacuum dried, and then stored at $-80^{\circ} \mathrm{C}$ for future use.

After collecting and multiplying urediniospores, we successfully recovered 961 samples from the 1,391 samples, including 702 samples from Gansu, Shaanxi, and Sichuan provinces collected in June 2009, and 259 samples from Tibet collected in June 2010 (Table 1).

DNA extraction. DNA was extracted directly from urediniospores of each isolate using the CTAB method (Wang et al. 2010b). A sample of $10 \mathrm{mg}$ fresh urediniospores were placed into a $1.5-\mathrm{ml}$ centrifuge tube and ground by electric drill on ice. Thirty microliters of lysis buffer containing $20 \% \mathrm{SDS}, 20 \mu \mathrm{l}$ of $5 \mathrm{~mol} / \mathrm{liter} \mathrm{NaCl}$, and $30 \mu \mathrm{l}$ of $\mathrm{CTAB} / \mathrm{NaCl}$ were added into each tube. The tubes were then incubated in a $65^{\circ} \mathrm{C}$ water bath for $1 \mathrm{~h}$, and inverted every $10 \mathrm{~min}$. Next, $400 \mu \mathrm{l}$ of phenol/chloroform/isoamyl alcohol $(25: 24: 1, \mathrm{pH}>7.8)$ was added to each tube; the tubes were shaken gently and then centrifuged at $12,500 \mathrm{rpm}$ for $10 \mathrm{~min}$ at $4{ }^{\circ} \mathrm{C}$. The aqueous phase was collected and DNA was precipitated with equal volume of isopropyl alcohol at $-20^{\circ} \mathrm{C}$ for 1 to $2 \mathrm{~h}$. The tubes were centrifuged at $12,500 \mathrm{rpm}$ for $15 \mathrm{~min}$ at $4^{\circ} \mathrm{C}$, the supernatant was discarded, and DNA pellet was washed twice with $70 \%$ ethanol, air-dried, and dissolved in $30 \mu \mathrm{l} \mathrm{TE}$ solution. DNA was purified by adding $4 \mu \mathrm{RNase} \mathrm{A}(10 \mathrm{mg} / \mathrm{ml})$ and incubated for $1 \mathrm{~h}$ at $37^{\circ} \mathrm{C}$. DNA concentration was then measured with a NanoDrop 2000 spectrophotometer (Thermal Co., U.S.A.), and DNA integrity was checked using agarose gel electrophoresis in a $1.0 \%$ agarose gel and visualized under AlphaImager System (CA, U.S.A.) after staining in an ethidium bromide solution $(0.5 \mu \mathrm{g} / \mathrm{ml})$ for $15 \mathrm{~min}$. DNA was diluted to $50 \mathrm{ng} / \mu \mathrm{l}$ and stored at $-80^{\circ} \mathrm{C}$ for future use.

PCR amplification and electrophoresis of SSR markers. Ten pairs of published SSR primers were used to genotype each isolate (Table 2): RJ18, RJ20, RJ21, and RJ24 were used as described in Enjalbert et al. (2002); CPS08, CPS09, CPS10, CPS15, CPS34, and CPS36 were used according to Chen et al. (2009). All SSR primers were synthesized by Life Technologies co., Shanghai, China. The PCR reaction system consisted of $25 \mu \mathrm{l}$ : 10× reaction buffer $2.5 \mu \mathrm{l}, \mathrm{MgCl}_{2}(25 \mathrm{mM}) 1.7 \mu \mathrm{l}, \mathrm{dNTP}(2.5 \mathrm{mM}) 2.0 \mu \mathrm{l}$, forward primer $(10 \mu \mathrm{M}) 0.5 \mu \mathrm{l}$, reverse primer $(10 \mu \mathrm{M}) 0.5 \mu \mathrm{l}$, Taq polymerase $(5 \mathrm{U} / \mu \mathrm{l}) 0.2 \mu \mathrm{l}$, DNA $(50 \mathrm{ng} / \mu \mathrm{l}) 1.0 \mu \mathrm{l}, \mathrm{ddH}_{2} \mathrm{O} 16.6 \mu \mathrm{l}$. The amplification conditions were as the following: a predenaturation step at $94^{\circ} \mathrm{C}$ for $4 \mathrm{~min}$ followed by 10 amplification cycles consisting of denaturation at $94^{\circ} \mathrm{C}$ for $45 \mathrm{~s}$, annealing at $64^{\circ} \mathrm{C}$ for $45 \mathrm{~s}$ (the temperature decreased by $0.7^{\circ} \mathrm{C}$ for every cycle), and extension at $72^{\circ} \mathrm{C}$ for $45 \mathrm{~s}$, with another 25 cycles of denaturation at $94^{\circ} \mathrm{C}$ for $45 \mathrm{~s}$, annealing at $54^{\circ} \mathrm{C}$ for $45 \mathrm{~s}$, extension $72^{\circ} \mathrm{C}$ for $45 \mathrm{~s}$, a final extension step at $72^{\circ} \mathrm{C}$ for $10 \mathrm{~min}$.

PCR products were separated on a $6 \%$ SDS-polyacrylamide gel electrophoresis (SDS-PAGE) in a sequence electrophoresis tank (DYCZ-20C, Beijing, China). The SDS-PAGE with electrophoresis glass plate was soaked in a $10 \%$ acetic acid and gently shaken until color indicator disappeared (approx. $30 \mathrm{~min}$ ), washed for $10 \mathrm{~min}$ in $\mathrm{ddH}_{2} \mathrm{O}$ twice, transferred into silver-staining solution $\left(1.7 \mathrm{~g} \mathrm{AgNO}_{3}\right.$ and $1,700 \mathrm{ml} \mathrm{ddH}_{2} \mathrm{O}$ ) and gently shaken for $30 \mathrm{~min}$, washed with

Table 1. Information of Puccinia striiformis f. sp. tritici samples collected from different regions in China

\begin{tabular}{|c|c|c|c|c|c|c|}
\hline Province & Geographical region & County & No. of fields & No. of samples collected & No. of samples recovered & Altitude (m) \\
\hline \multirow[t]{6}{*}{ Gansu } & Tianshui & Qinzhou & 5 & & 72 & $1,320-1,750$ \\
\hline & & Qinan & 3 & & 33 & \\
\hline & & Maiji & 3 & & 36 & \\
\hline & Pingliang & Kongtong & 4 & & 49 & $1,100-1,600$ \\
\hline & Longnan & Wenxian & 4 & & 56 & $800-2,100$ \\
\hline & & Wudu & 3 & & 31 & \\
\hline Subtotal & & & 22 & 347 & 277 & \\
\hline \multirow[t]{12}{*}{ Sichuan } & Aba & Jiuzaigou & 3 & & 24 & $2,850-3,000$ \\
\hline & & Songpan & 4 & & 24 & \\
\hline & & Heishui & 3 & & 23 & \\
\hline & Liangshan & Dechang & 3 & & 16 & $1,100-1,700$ \\
\hline & & Huili & 2 & & 42 & \\
\hline & Guangyuan & Yuanba & 3 & & 9 & $1,000-1,950$ \\
\hline & & Jiange & 3 & & 22 & \\
\hline & Mianyang & Zitong & 3 & & 18 & $500-1,800$ \\
\hline & Chengdu & Jintang & 2 & & 28 & $450-900$ \\
\hline & Yibin & Yibin & 3 & & 7 & $550-950$ \\
\hline & & Pingshan & 3 & & 30 & \\
\hline & & Cuiping & 2 & & 10 & \\
\hline Subtotal & & & 34 & 349 & 253 & \\
\hline \multirow[t]{7}{*}{ Shaanxi } & Baoji & Longxian & 3 & & 26 & $700-1,100$ \\
\hline & & Chencang & 3 & & 20 & \\
\hline & & Qianyang & 4 & & 20 & \\
\hline & & Fenxiang & 2 & & 28 & \\
\hline & Hanzhong & Ningqiang & 3 & & 26 & $300-550$ \\
\hline & & Mianxian & 3 & & 30 & \\
\hline & Ankang & Hanbin & 2 & & 22 & $800-1,900$ \\
\hline Subtotal & & & 20 & 200 & 172 & \\
\hline \multirow[t]{4}{*}{ Tibet } & Linzhi & Miling & 7 & & 94 & $2,450-3,760$ \\
\hline & & Linzhi & 5 & & 69 & \\
\hline & & Bomi & 5 & & 91 & \\
\hline & & Gongbujiangda & 3 & & 5 & \\
\hline Subtotal & & & 20 & 495 & 259 & \\
\hline Total & & & 96 & 1,391 & 961 & \\
\hline
\end{tabular}


$\mathrm{ddH}_{2} \mathrm{O}$, soaked into a developer solution ( $40 \mathrm{~g} \mathrm{NaOH}, 400 \mu \mathrm{lammo-}$ nium persulfate, $3 \mathrm{ml}$ formaldehyde, and $2,000 \mathrm{ml} \mathrm{ddH}_{2} \mathrm{O}$ ) until bands of desired intensity appeared (approx. $10 \mathrm{~min}$ ). Then, the gel was immersed in a $5 \%$ acetic acid solution for about $5 \mathrm{~min}$. The SDS-PAGE was dried and scanned into computer using a scanner. The bands were scored using automatic molecular weight calculation based on standard molecular ladder under the AlphaView Software (Alpha Innotech, CA, U.S.A.). The experiment was repeated twice. Only stable bands were recorded. To verify the motifs, 50 SSR products (representing a range of sizes for each SSR marker) were randomly selected and sequenced with an ABI 373A automated DNA sequencer (Life Technologies co., Shanghai, China).

Amplicon size categories at each locus were considered unique alleles that were compiled across loci into multilocus genotypes (MLGs). Isolates with identical MLGs in the same population were considered clonets (Tibayrenc and Ayala 2002, 2012). Data from only one representative of each clonet was incorporated into clone-corrected datasets for analysis using GenoDive 2.0 beta version (Meirmans and Hedrick 2011) and Multilocus version 3.1 (Agapow and Burt 2001).

Analysis of population subdivision. We used multivariate and model-based Bayesian clustering approaches to infer population subdivision. Multivariate discriminant analyses of principal components (DAPC), implemented in the ADEGENET package in R environment (Jombart 2008), were performed to identify partitions within the dataset, regardless of the geographic origin of samples. This method makes no assumption regarding data structure or underlying population genetics model. The $k$-means were used to run sequentially with increasing values of $\mathrm{k}$ (number of clusters), and different clustering solutions were compared using Bayesian Information Criterion (BIC) to identify the optimal number of clusters (Jombart et al. 2010).

In addition to nonparametric analysis (i.e., DAPC), a model-based Bayesian method implemented in STRUCTURE 2.2 (Falush et al. 2003; Pritchard et al. 2000) was used to identify genetic clusters and to evaluate the extent of admixture among them. A model allowing admixture and independent allele frequencies among populations was used. For each simulated cluster $K(K=1-20)$, 50 runs were performed with 400,000 iterations in Monte Carlo Markov Chain replications and a burn-in period of 100,000. The outputs were processed with CLUMPP 1.1.2 (Jakobsson and Rosenberg 2007) and G'-statistic $>80 \%$ (Nei 1973) was used as a criterion to assign runs into a common clustering pattern. STRUCTURE output was used as an input file to STRUCTURE HARVESTER (http://taylor0.biology.ucla. edu/structureHarvester) to estimate the optimal number of clusters $(\mathrm{K})$. The ad hoc statistic $\Delta \mathrm{K}$, which is based on the rate of change in the log probability, was calculated to identify the optimal number of clusters (K) (Evanno et al. 2005).

Analysis of genetic variation within and among clusters. Two classifications were used to group strains for within- and betweengroup analysis. The first one is the genetic clusters identified by DAPC and STRUCTURE; the second was the geographic location. Clonal fractions $(\mathrm{CF})$ were calculated as:

$\mathrm{CF}=1-[($ number of different MLGs)/(total number of isolates) $]$

Allele frequencies, the number of alleles per locus, and gene diversity $(\mathrm{H})$ were calculated using POPGENE 1.32 (Yeh et al. 1999). Allelic richness (AR) and private allelic richness (PAR) were calculated using ADZE (Szpiech et al. 2008), which uses a rarefaction procedure to adjust variation in sample size across populations. AR is the average number of alleles per locus corrected for sample size (Dilmaghani et al. 2012). PAR is the number of unique alleles exclusive to single populations (Dilmaghani et al. 2012; Szpiech et al. 2008). Gene diversity was calculated for each group of isolates, which estimates the probability that two alleles chosen at random from a given population are different (Nei 1973, 1978). Pairwise measures of differentiation between clusters were estimated from a corrected standardized fixation index $\left(\mathrm{G}^{\prime \prime}{ }_{\mathrm{ST}}\right)$ using GENODIVE 2.0 beta version (Hedrick 2005; Meirmans and Hedrick 2011). Gene flow ( $N_{m}$, number of migrants) between Pst populations was estimated as: $N_{m}=0.25 \times\left(1-\mathrm{G}^{\prime \prime}{ }_{\mathrm{ST}}\right) / \mathrm{G}^{\prime \prime}{ }_{\mathrm{ST}} . N_{m}<1$ and $\geq 1$ imply little and considerable amount of gene flow between populations, respectively (Culley et al. 2002; Wright 1951).

Linkage disequlibrium analysis. The linkage disequlibrium (LD) tests were performed for each cluster (or subpopulation) separately. Only clusters and subpopulations with at least 10 clone corrected isolates were used for LD analysis. The standardized index of association (rBarD), an alternative measure of the index of association $\left(\mathrm{I}_{\mathrm{A}}\right)$ adjusted for the number of loci, was used to assess the significance of LD using Multilocus version 3.1 (Agapow and Burt 2001). The rBarD values range from 0 to 1 ; an $\mathrm{rBarD}$ value of 0 corresponds to a random association of alleles at different loci (linkage equilibrium), whereas an $\mathrm{rBarD}$ value of 1 indicates a complete association of alleles at different loci (complete linkage disequilibrium) (Agapow and Burt 2001). The significance of rBarD was assessed with a randomization test. Under the null hypothesis of $\mathrm{rBarD}=0$, 1,000 sets of data were randomly drawn from the data, representing 1,000 realizations under the null hypothesis; $\mathrm{rBarD}$ was calculated for each realization. Statistical significance of the observed $\mathrm{rBarD}$ value was assessed by its comparison with the 1,000 rBarD values generated under the $\mathrm{rBarD}=0$ hypothesis.

Table 2. SSR primer pairs of Puccinia striiformis $\mathrm{f}$. sp. tritici used in this study

\begin{tabular}{|c|c|c|c|c|c|c|}
\hline Primer name & Primer sequence $\left(5^{\prime}-3^{\prime}\right)$ & $\begin{array}{c}\text { Repeat } \\
\text { motif }\end{array}$ & $\begin{array}{c}\text { Annealing } \\
\text { temperature }\left({ }^{\circ} \mathbf{C}\right)\end{array}$ & $\begin{array}{l}\text { Expected range of } \\
\text { fragment sizes (bp) }\end{array}$ & $\begin{array}{l}\text { No. of } \\
\text { alleles }\end{array}$ & Reference \\
\hline$\overline{\mathrm{CPS} 08 \mathrm{~F}}$ & GATAAGAAACAAGGGACAGC & $(\mathrm{CAG})_{14}$ & 55 & $221-227$ & 3 & Chen et al. 2009 \\
\hline CPS08R & CAGTGAACCCAATTACTCAG & & & & & \\
\hline CPS09F & CGGGAGAAGACCTGAGC & $(\mathrm{GTT})_{9}$ & 58 & $379-407$ & 9 & Chen et al. 2009 \\
\hline CPS09R & AGAAAACGGAATGTAATGTG & & & & & \\
\hline CPS10F & TCTACTGGGCAGACTGGTC & $(\mathrm{TAG})_{8}$ & 56 & $335-341$ & 4 & Chen et al. 2009 \\
\hline CPS10R & CGGTTTGTTTTGTCGTTTC & & & & & \\
\hline CPS15F & GATGGGGAAAAGTAAGAAGT & $(\mathrm{TTC})_{4}$ & 58 & $236-245$ & 3 & Chen et al. 2009 \\
\hline CPS15R & GGTGGGGGATGTAAGTATGTA & & & & & \\
\hline CPS34F & GTTGGCTACGAGTGGTCATC & $(\mathrm{TC})_{9}$ & 58 & $131-138$ & 3 & Chen et al. 2009 \\
\hline CPS34R & TAACACTACACAAAAGGGGTC & & & & & \\
\hline CPS36F & TCCAGGCAGTAAATCAGACGC & $(\mathrm{GCA})_{6}$ & 54 & $145-149$ & 2 & Chen et al. 2009 \\
\hline CPS36R & ATCAGCAGGTGTAGCCCCATC & & & & & \\
\hline RJ18F & CTGCCCATGCTCTTCGTC & $(\mathrm{TGT})_{5}$ & 56 & $220-376$ & 4 & Enjalbert et al. 2002 \\
\hline RJ18R & GATGAAGTGGGTGCTGCTG & & & & & \\
\hline RJ20F & AGAAGATCGACGCACCCG & $(\mathrm{CAG})_{4}$ & 56 & 300-309 & 4 & Enjalbert et al. 2002 \\
\hline RJ20R & CCTCCGATTGGCTTAGGC & & & & & \\
\hline $\mathrm{RJ} 21 \mathrm{~F}$ & TTCCTGGATTGAATTCGTCG & $(\mathrm{GTT})_{6}$ & 58 & $200-226$ & 2 & Enjalbert et al. 2002 \\
\hline RJ21R & CAGTTCTCACTCGGACCCAG & & & & & \\
\hline $\mathrm{RJ} 24 \mathrm{~F}$ & TTGCTGAGTAGTTTGCGGTGAG & $(\mathrm{GTT})_{5+9}$ & 54 & $287-315$ & 9 & Enjalbert et al. 2002 \\
\hline RJ24R & CTCAAGCCCATCCTCCAACC & & & & & \\
\hline
\end{tabular}


Regression analysis. The relationship of population differentiation $\left(\mathrm{G}^{\prime \prime}{ }_{\mathrm{ST}}\right)$ with geographical distances among all pairs of 13 Pst subpopulations was assessed by a regression analysis (PROC GLM procedure in SAS version 9.3; SAS Institute). G" ${ }_{\text {ST }}$ was computed using GENODIVE 2.0 beta version and the geographical distances (straight line distance) were estimated using Google Earth from the region center.

\section{Results}

SSR analysis. Of 1,391 wheat leaf samples collected from Gansu (347), Shaanxi (200), Sichuan (349), and Tibet (495), 961 isolates (Table 1) were recovered and multiplied. The 10 SSR primer pairs produced 43 polymorphic SSR loci.
Estimation of genetic clusters. STRUCTURE analysis supported two clusters (Fig. S2). When $K=2$, the two clusters corresponded to the Tibet region and the other regions: Mingling, Linzhi, Bomi, and Gongbujiangda counties in Tibet; and all of the counties in the other regions (Fig. 1). Increasing $K$ to 3 or 4 only led to further divisions of samples from the other regions into subgroups. For $K=3$, one main epidemic region cluster included Pst isolates mainly from Qinzhou, Qinan, Maji, Kongtong, and Wenxian in Gansu Province, Jiuzaigou, Sunpan, Huili, Yuanba, Jiange, Zitong, Jintang, Yibin, and Cuiping in Sichuan Province, Longxian, Chencang, Qianyang, Fengxiang, Ningqiang, and Mianxian in Shaanxi Province; the other cluster comprised all the other isolates from the other regions. For $K=4$, isolates from the main epidemic region were divided into three clusters:

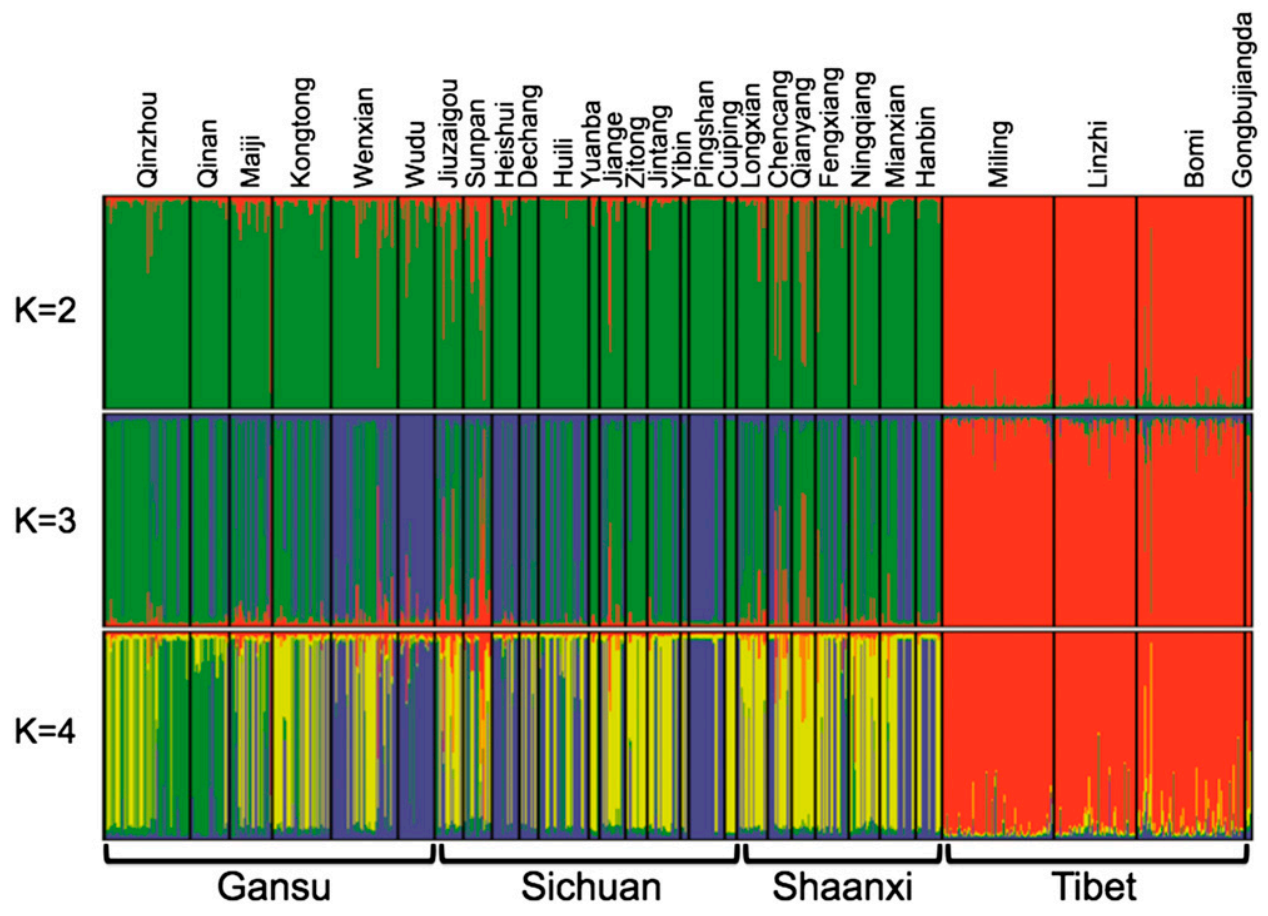

Fig. 1. Bayesian clustering of Puccinia striiformis f. sp. tritici isolates in China using STRUCTURE version 2.2 .3 (Pritchard et al. 2000). Several outputs are presented, corresponding to the different values of $K$ (from 2 to 4 ) that most efficiently summarize the data. Each individual is represented by a vertical line partitioned into $K$ colored segments that represent the probability that the individual belongs to each of $K$ clusters. Black lines separate individuals from different populations.
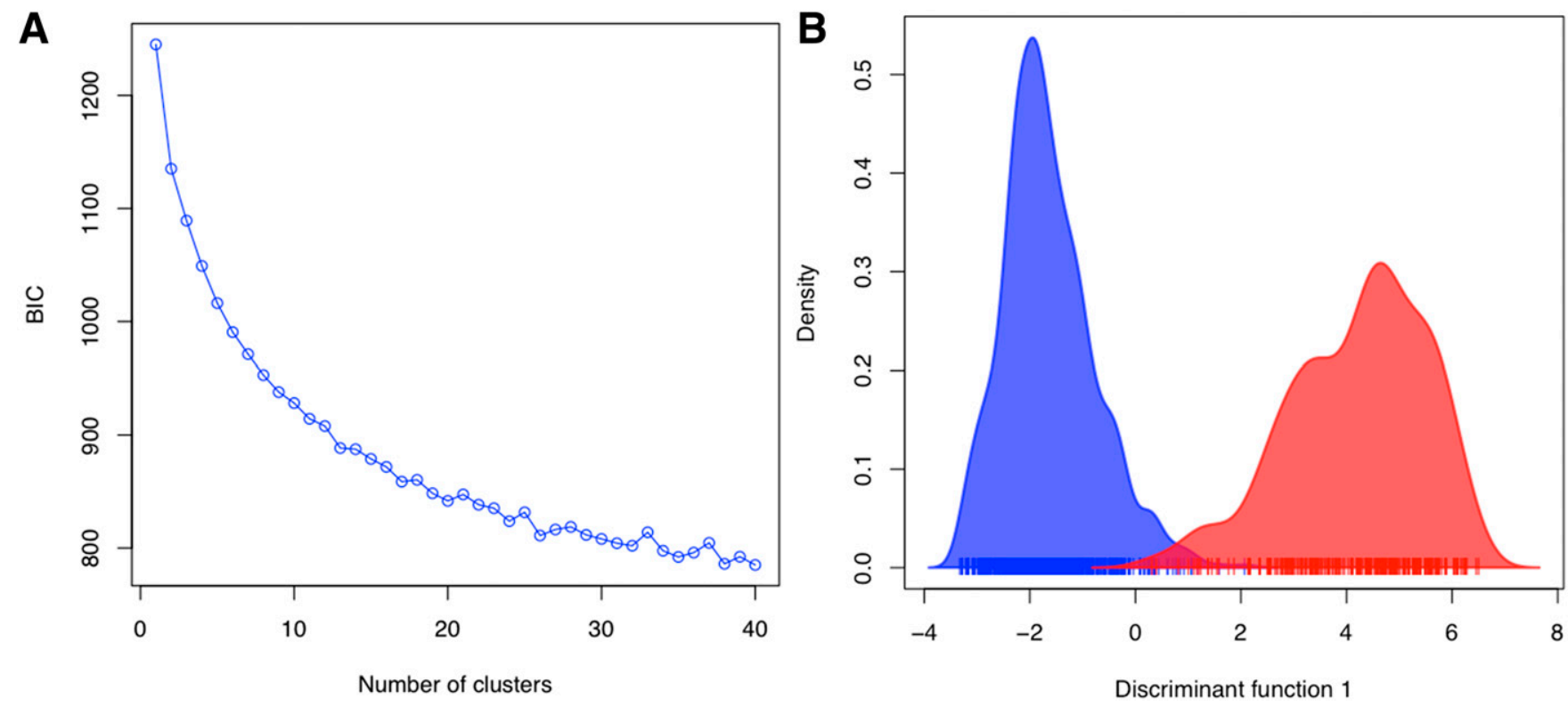

Fig. 2. Discriminant analysis of principal components (DAPC) (Jombart et al. 2010) on 961 Puccinia striformis f. sp. tritici (Pst) genotypes. A, Value of Bayesian information criterion (BIC) versus number of clusters for all Pst genotypes. B, Scatter-plot of the DAPC on a set of 961 Pst genotypes from all epidemic regions. Colors represent the two genetic clusters found by the K-means method (see Jombart et al. 2010 for details). 
cluster 1 contained isolates from Qinzhou, Qinan, Maiji, and Kongtong in Gansu Province; cluster 2 contained isolates from Wenxian and Wudu in Gansu Province; Heishui, Dechang, Huili, Yibin, Pingshan in Sichuan Province; Chengcang, Mianxian, and Hanbin in Shaanxi Province; cluster 3 contained all the other isolates.

Nonparametric DAPC also suggested two clusters (Fig. 2) though the support is not as strong as the STRUCTURE analysis (Fig. 1). Cluster 2 and 1 comprised mainly isolates from the Tibet region and the other regions, respectively, consistent with the clusters derived from the STRUCTURE analysis (Table 3). DAPC grouped four isolates from Tibet with isolates from the other regions, compared with such a classification for only one isolate by STRUCTURE analysis. The 700 isolates in cluster 1 comprised three subclusters (Fig. 3). Subcluster 1 consisted mainly of those isolates from Mianyang, Pingliang, Baoji, Ankang, and Hanzhong; subcluster 2 mainly of isolates from Longnan, Yibin, Liangshan, and Ankang; subcluster 3 mainly of isolates from Guangyuan, Chengdu, and Tianshui. Isolates from Tianshui, Pingliang, Longnan, Baoji, Hanzhong, Ankang, Guangyuan, Mianyang, Aba, Chengdu, Liangshan, and Yibin were distributed into three subclusters (Fig. 4).

Genetic diversity. Table 4 gives clonal fractions (CF), gene diversity $(H)$, and allelic richness (AR) and private allelic richness (PAR) for the two DAPC clusters. The clonal fraction was 0.30 for cluster 1 $(N=700)$ and 0.26 for cluster $2(N=261)$. The CF of all Pst isolates was 0.29 . The gene diversitywas 0.307 for cluster 1 and 0.336 for cluster 2. The allelic richness was 1.749 for cluster 1 and 1.830 for cluster 2 ; the corresponding value of private allelic richness was 0.153 and 0.235 , respectively.

Cluster 1 included 12 subpopulations (Tianshui, Pingliang, Longnan, Aba, Liangshan, Gyuangyuan, Mianyang, Chengdu, Yibin,
Baoji, Hanzhong, and Ankang). CF values of these subpopulations ranged from 0.11 for Longnan $(N=58)$ to 0.74 for Yibin $(N=74)$ (mean: 0.338$). H$ values ranged from 0.179 for Liangshan $(N=58)$ to 0.307 for Tianshui $(N=140)$ (mean: 0.243$)$ (Table 4$)$. AR values ranged from 1.514 for Liangshan to 1.843 for Longnan (mean: 1.697); PAR values were close to 0 (Table 4 ) for all 12 subpopulations. Cluster 2 included Linzhi subpopulation only; $\mathrm{CF}, H, \mathrm{AR}$, and PAR values were $0.26,0.336,1.830$, and 0.235 , respectively.

The relationship between population differentiation $\left(\mathrm{G}_{\mathrm{ST}}{ }_{\mathrm{ST}}\right)$ and geographical distance was approximately linear $\left(\mathrm{R}^{2}=0.626\right)$ (Fig. $5)$. The distance between the Linzhi subpopulation and each of Tianshui, Pingliang, Longnan, Aba, Liangshan, Gyuangyuan, Mianyang, Chengdu, Yibin, Baoji, Hanzhong, and Ankang subpopulation is $>1,500 \mathrm{~km}$; the $\mathrm{G}^{\prime \prime}{ }_{\mathrm{ST}}$ values were all $>0.3$. The distances among Tianshui, Pingliang, Longnan, Aba, Liangshan, Gyuangyuan, Mianyang, Chengdu, Yibin, Baoji, Hanzhong, and Ankang subpopulation are all $<1,500 \mathrm{~km}$; the $\mathrm{G}^{\prime \prime}$ sT values were all $<0.3$ (Fig. 5).

Population differentiation. Corrected standardized population differentiation $\left(\mathrm{G}_{\mathrm{ST}}^{\prime \prime}\right)$ values of two DAPC clusters indicated that the two clusters were highly differentiated, with $\mathrm{G}^{\prime \prime}{ }_{\text {ST }}$ values of $0.323(P<0.001)$. At the subpopulation level, most $\mathrm{G}^{\prime \prime}{ }_{\mathrm{ST}}$ values between subpopulations from different clusters were greater than zero, namely P13 (Linzhi from cluster 2) with other 12 subpopulations from cluster $1(P<0.001)$ (Table 5$)$. There was no significant difference $(P>0.05)$ between Pingliang subpopulation $(\mathrm{P} 2)$ and each of (Mianyang) P7, (Chengdu) P8, (Yibin) P9, (Baoji) P10, and (Ankang) P12 subpopulation; Tianshui (P1) and Mianyang (P7); Longnan (P3) and Ankang (P12); Liangshan (P5) and Yibin (P9); Guangyuan (P6) and each of Mianyang (P7) and Chengdu (P8); Mianyang (P7) and each of Chengdu (P8), Yibin (P9), Baoji (P10), and

Table 3. Classification of 961 strains of Puccinia striiformis f. sp. tritici using STRUCTURE version 2.2.3 (Pritchard et al. 2000) and the discriminant analysis of principal components (DAPC) (Jombart et al. 2010)

\begin{tabular}{|c|c|c|c|c|c|c|c|c|c|c|}
\hline \multirow[b]{3}{*}{ Method } & \multicolumn{4}{|c|}{$K=2$} & \multicolumn{6}{|c|}{$K=\mathbf{3}$} \\
\hline & \multicolumn{2}{|c|}{ Cluster 1} & \multicolumn{2}{|c|}{ Cluster 2} & \multicolumn{2}{|c|}{ Cluster 1} & \multicolumn{2}{|c|}{ Cluster 2} & \multicolumn{2}{|c|}{ Cluster 3} \\
\hline & $\begin{array}{l}\text { Individual } \\
\text { number } \\
\text { from main } \\
\text { epidemic } \\
\text { region } / \% \text { a }\end{array}$ & $\begin{array}{l}\text { Individual } \\
\text { number } \\
\text { from Tibet } \\
\text { epidemic } \\
\text { region/\% }\end{array}$ & $\begin{array}{l}\text { Individual } \\
\text { number } \\
\text { from main } \\
\text { epidemic } \\
\text { region } / \% \text { a }\end{array}$ & $\begin{array}{c}\text { Individual } \\
\text { number } \\
\text { from Tibet } \\
\text { epidemic } \\
\text { region/\%b }\end{array}$ & $\begin{array}{l}\text { Individual } \\
\text { number } \\
\text { from main } \\
\text { epidemic } \\
\text { region } / \% \text { a }\end{array}$ & $\begin{array}{l}\text { Individual } \\
\text { number } \\
\text { from Tibet } \\
\text { epidemic } \\
\text { region } / \% \text { b }\end{array}$ & $\begin{array}{c}\text { Individual } \\
\text { number } \\
\text { from } \\
\text { main } \\
\text { epidemic } \\
\text { region } / \% \text { a }\end{array}$ & $\begin{array}{c}\text { Individual } \\
\text { number } \\
\text { from Tibet } \\
\text { epidemic } \\
\text { region } / \% \text { b }\end{array}$ & $\begin{array}{c}\text { Individual } \\
\text { number } \\
\text { from main } \\
\text { epidemic } \\
\text { region } / \% \text { a }\end{array}$ & $\begin{array}{l}\text { Individual } \\
\text { number } \\
\text { from Tibet } \\
\text { epidemic } \\
\text { region } / \% \text { b }\end{array}$ \\
\hline STRUCTURE & $702 / 100.0$ & $0 / 0.0$ & $0 / 0.0$ & $259 / 100.0$ & $296 / 42.2$ & $0 / 0.0$ & $395 / 56.3$ & $2 / 0.8$ & $11 / 1.6$ & $257 / 99.2$ \\
\hline DAPC & 696 / 99.1 & $4 / 1.5$ & $6 / 0.9$ & $255 / 98.5$ & $288 / 41.0$ & $0 / 0.0$ & $410 / 58.4$ & $4 / 1.5$ & $4 / 0.6$ & $255 / 98.5$ \\
\hline
\end{tabular}

a The proportion was calculated using the individual number of the cluster and total individual number of the main epidemic region.

$\mathrm{b}$ The proportion was calculated using the individual number of the cluster and total individual number of the Tibet epidemic region.

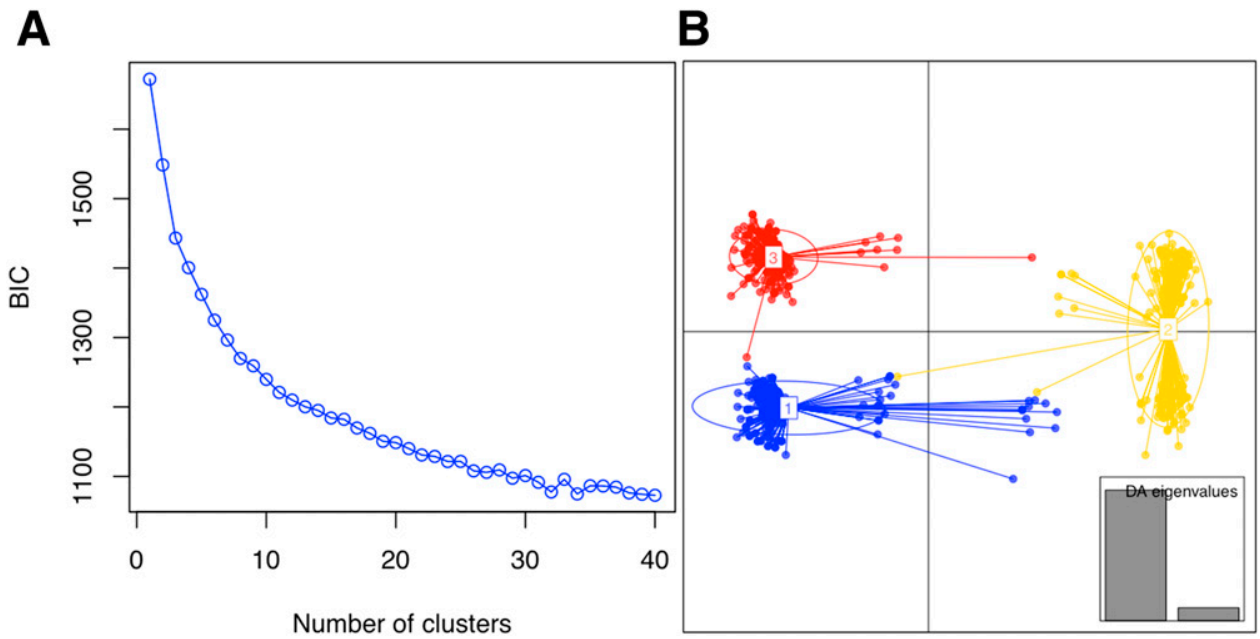

Fig. 3. Discriminant analysis of principal components (DAPC) (Jombart et al. 2010) on 702 Puccinia striiformis $\mathrm{f}$. sp. tritici (Pst) genotypes from the main epidemic region. A, Value of Bayesian information criterion (BIC) versus number of clusters for 702 Pst genotypes from the main epidemic region. B, Scatter-plot of the DAPC on a set of 702 Pst genotypes from the main epidemic region. At the bottom right, the eigenvalues of the first two axes are represented. Genotypes are represented by dots and clusters as ellipses. 
Ankang (P12); Chengdu (P8) and Yibin (P9); Baoji (P10) and Ankang (P12); and Hanzhong (P11) and Ankang (P12) (Table 5).

Linkage disequilibrium. The clusters determined by DAPC analysis were used for multilocus linkage disequilibrium (LD) analysis.

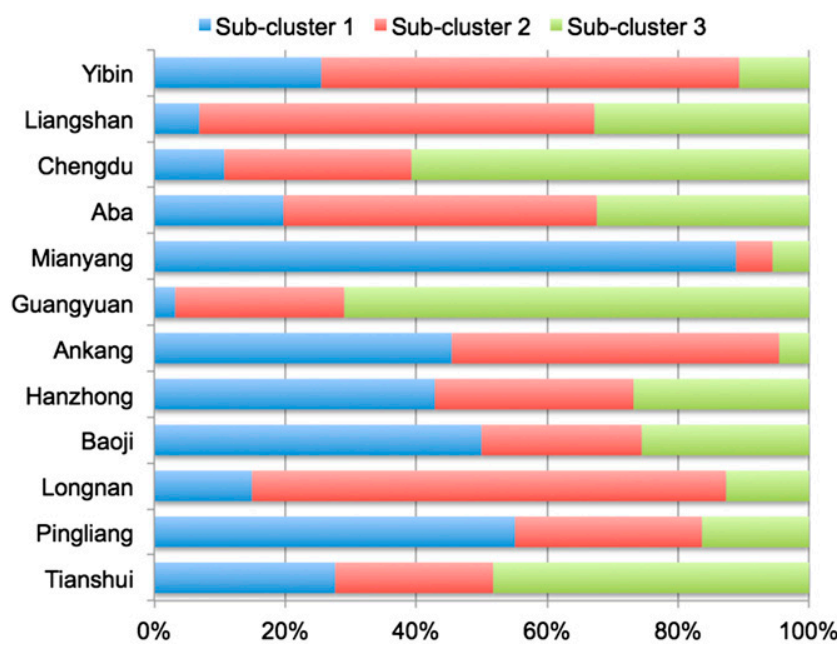

Fig. 4. Subclusters based on the discriminant analysis of principal components (DAPC) (Jombart et al. 2010) performed on 702 individuals of Puccinia striformis f. sp. tritici genotypes from main epidemic region in China.
The LD value was significantly greater than 0 for both clusters $(P=0.01)$. However, subpopulations from Longnan, Liangshan, Mianyang, Chengdu, and Hanzhong in cluster 1 had LD values that were not statistically different from $0(P>0.05)$ (Table 4; Fig. S3).

Gene flow of $P$ st among populations. Populations in the other regions including Gansu, Shaanxi, and Sichuan had extensive gene exchanges as $N_{m}$ were $6.17,7.55$, and 4.71 for Gansu/Sichuan, Gansu/ Shaanxi, and Sichuan/Shaanxi, respectively; whereas low gene flows were detected between Tibet and other provinces (Gansu, Shaanxi, and Sichuan): $N_{m}$ values were all close to 0.4 .

\section{Discussion}

The Pst epidemiology in the epidemic regions except Tibet and Xinjiang in China had been well studied (Hu et al. 2000; Li and Liu 1957; Lu et al. 2011; Shen et al. 2008; Wang et al. 2010a,b; Xie et al. 1986, 1988; Zeng and Luo 2006, 2008). Zeng and Luo (2006) proposed 15 different epidemic subregions in the main epidemiological region in China based on geographic, climatic, cropping, and rust epidemic features. In the main Pst epidemiological region, the genetic diversity was relatively high and the majority of genetic variation occurred within populations. The Longnan population had the highest genetic diversity in the main epidemiological region in China (Chen 2008; Lu et al. 2011). In contrast, few reports were on the Xinjiang and Tibet epidemic regions. The Pst population in Xinjiang had a higher genetic diversity than populations in Qinghai, Gansu, Ningxia, and Tibet. Twenty-seven previously known and eight unknown races were detected in Xinjiang, higher than in other epidemiological regions (Zhan et al. 2016). The composition of

Table 4. Genetic diversity of Puccinia striiformis f. sp. tritici populations analyzed with 43 microsatellite loci

\begin{tabular}{|c|c|c|c|c|c|c|c|c|c|c|}
\hline \multicolumn{2}{|c|}{ Population } & \multirow{2}{*}{$\begin{array}{c}\begin{array}{c}\text { Berberis sp. (Zhao } \\
\text { et al. 2013; } \\
\text { Wang et al. 2016) }\end{array} \\
\begin{array}{l}\text { B. brachypoda } \\
\text { B. aggregate }\end{array}\end{array}$} & \multirow{2}{*}{$\begin{array}{c}\begin{array}{c}\text { Sample } \\
\text { size }\end{array} \\
140\end{array}$} & \multirow{2}{*}{$\begin{array}{c}\begin{array}{c}\text { Clone } \\
\text { corrected }\end{array} \\
119\end{array}$} & \multirow{2}{*}{$\begin{array}{c}\begin{array}{c}\text { Clonal } \\
\text { fraction }^{\mathbf{a}}\end{array} \\
0.15\end{array}$} & \multirow{2}{*}{$\begin{array}{c}\begin{array}{c}\text { Genotypic } \\
\text { richness }\end{array} \\
0.85\end{array}$} & \multirow{2}{*}{$\begin{array}{c}\begin{array}{c}\text { Gene } \\
\text { diversity } \\
\left(\mathbf{H}^{\mathbf{b}}\right)\end{array} \\
0.307( \pm 0.19)\end{array}$} & \multirow{2}{*}{$\begin{array}{c}\begin{array}{c}\text { Allelic } \\
\text { richness }\end{array} \\
1.773( \pm 0.08)\end{array}$} & \multirow{2}{*}{$\begin{array}{c}\begin{array}{c}\text { Private } \\
\text { allelic } \\
\text { richness }^{\mathbf{c}}\end{array} \\
0\end{array}$} & \multirow{2}{*}{$\frac{\text { rBarD }^{\mathbf{d}}}{0.1757 * *}$} \\
\hline Cluster 1 & Tianshui & & & & & & & & & \\
\hline & Pingliang & $\mathrm{NI}^{\mathrm{e}}$ & 49 & 39 & 0.21 & 0.79 & $0.254( \pm 0.18)$ & $1.735( \pm 0.09)$ & 0 & $0.054 * *$ \\
\hline & Longnan & $\begin{array}{l}\text { B. aggregate } \\
\text { B. soulieana } \\
\text { B. stenostachya } \\
\text { B. brachypoda }\end{array}$ & 86 & 77 & 0.11 & 0.89 & $0.301( \pm 0.16)$ & $1.843( \pm 0.06)$ & 0 & 0.005797 \\
\hline & Aba & $\mathrm{NI}$ & 70 & 50 & 0.29 & 0.71 & $0.257( \pm 0.19)$ & $1.718( \pm 0.08)$ & $0.001 \pm 0.001$ & $0.02643 * *$ \\
\hline & Liangshan & NI & 58 & 27 & 0.54 & 0.46 & $0.179( \pm 0.21)$ & $1.514( \pm 0.10)$ & 0 & 0.01584 \\
\hline & Guangyuan & B. soulieana & 31 & 24 & 0.23 & 0.77 & $0.263( \pm 0.19)$ & $1.753( \pm 0.09)$ & 0 & 0.01763 \\
\hline & Mianyang & B. soulieana & 18 & 10 & 0.47 & 0.53 & $0.197( \pm 0.17)$ & $1.700( \pm 0.11)$ & 0 & 0.02573 \\
\hline & Chengdu & B. atrocarpa & 28 & 21 & 0.26 & 0.74 & $0.228( \pm 0.17)$ & $1.715( \pm 0.10)$ & 0 & 0.004653 \\
\hline & Yibin & $\mathrm{NI}$ & 47 & 13 & 0.74 & 0.26 & $0.213( \pm 0.22)$ & $1.550( \pm 0.11)$ & 0 & $0.05625 * *$ \\
\hline & Baoji & $\begin{array}{l}\text { B. shensiana } \\
\text { B. circumserrata } \\
\text { B. potaninii }\end{array}$ & 93 & 54 & 0.42 & 0.58 & $0.247( \pm 0.19)$ & $1.711( \pm 0.09)$ & 0 & $0.01674 * *$ \\
\hline & Hanzhong & B. dasystachya & 55 & 40 & 0.28 & 0.72 & $0.229( \pm 0.17)$ & $1.701( \pm 0.09)$ & 0 & 0.001043 \\
\hline & Ankang & B. soulieana & 21 & 14 & 0.35 & 0.65 & $0.242( \pm 0.21)$ & $1.650( \pm 0.11)$ & 0 & $0.1202 * *$ \\
\hline & Linzhi & & 4 & 4 & 0.00 & 1.00 & & $\mathrm{NA}^{\mathrm{f}}$ & NA & NA \\
\hline & Cluster 1 total & & 700 & 492 & 0.30 & 0.70 & $0.307( \pm 0.17)$ & $1.749( \pm 0.07)$ & $0.153( \pm 0.04)$ & 0.01624 \\
\hline \multirow[t]{8}{*}{ Cluster 2} & Tianshui & & 1 & 1 & NA & NA & NA & NA & NA & NA \\
\hline & Longnan & & 1 & 1 & NA & NA & NA & NA & NA & NA \\
\hline & Aba & & 1 & 1 & NA & NA & NA & NA & NA & NA \\
\hline & Baoji & & 1 & 1 & NA & NA & NA & NA & NA & NA \\
\hline & Hanzhong & & 1 & 1 & NA & NA & NA & NA & NA & NA \\
\hline & Ankang & & 1 & 1 & NA & NA & NA & NA & NA & NA \\
\hline & Linzhi & B. polyantha & 255 & 187 & 0.27 & 0.73 & $0.332( \pm 0.14)$ & $1.901( \pm 0.03)$ & $0.056( \pm 0.04)$ & 0.02083 \\
\hline & Cluster 2 total & & 261 & 193 & 0.26 & 0.74 & $0.336( \pm 0.14)$ & $1.830( \pm 0.04)$ & $0.235( \pm 0.07)$ & 0.02362 \\
\hline
\end{tabular}

a Clonal fraction was calculated as 1-[(number of MLGs) / (total number of isolates)] (Zhan et al. 2002).

${ }^{\mathrm{b}}$ Gene diversity within populations was calculated from clone-corrected data at 20 microsatellite loci (Yeh et al. 1999). Value inside the parenthesis is standard deviation.

${ }^{\mathrm{c}}$ Allelic richness and private allelic richness were calculated using ADZE that uses rarefaction. Value inside the parentheses is standard deviations.

${ }^{\mathrm{d}}$ Multilocus linkage disequilibrium $(L D)$ was assessed using the standardized index of association $(r B a r D)$ and estimated for each population as described previously (Agapow and Burt 2001). The significance of $r$ BarD was tested with 1,000 randomizations of the data by comparing the observed value to that expected under the null hypothesis of $r B a r D=0$. The null hypothesis of $L D$ was rejected if $P<0.01$. ** Significant at $P=0.01$

e NI, not investigated.

${ }^{\mathrm{f}} \mathrm{NA}$, not analyzed. 
Pst races in Tibet was different from that in Yunan, Qinghai, and Shaanxi (Hu et al. 2012).

Several studies have showed dispersal of $P s t$ in different geographic regions or temporal dynamics using DNA markers. The clonal structure in the Northwest European Pst population was confirmed using AFLP (Hovmøller et al. 2002). Similar results were obtained in Australia based on RAPD and AFLP markers (Steele et al. 2001). In China, Gansu and Sichuan provinces have been considered as the major sources of inoculum and new virulence (Wu and Niu 2000) as $P s t$ can over-summer in these regions (including Qinghai Province). The genetic diversity in the Longnan region was much higher than in the Linxia and Qinghai regions (Lu et al. 2011). Pst population in Longnan is genetically diverse and undergoes extensive genetic exchange within the region ( $\mathrm{Lu}$ et al. 2009; Zheng et al. 2005), which is supported by the present results. Pst genetic diversity in Southeast and Southwest Sichuan was lower than in the Sichuan basin and Gansu Province, which could be related to local climate, environment, geography, and wheat varieties. Chen (2008) studied 20 natural populations of $P s t$ in the main epidemiological region and found that the $N_{m}$ values of Shaanxi and Gansu ranged from 1.1 to 9.0 , and the highest $N_{m}$ value (8.9692) was observed between Piangliang (Gansu) and Baoji (Shaanxi). In contrast, the $N_{m}$ values between Gansu and Sichuan varied from 1.1 to 2.5 and $N_{m}$ values between Shaanxi and Sichuan varied from 1.1 to 2.7. These results are supported by the present study although the $N_{m}$ values in this study were higher than previous study (Chen 2008).

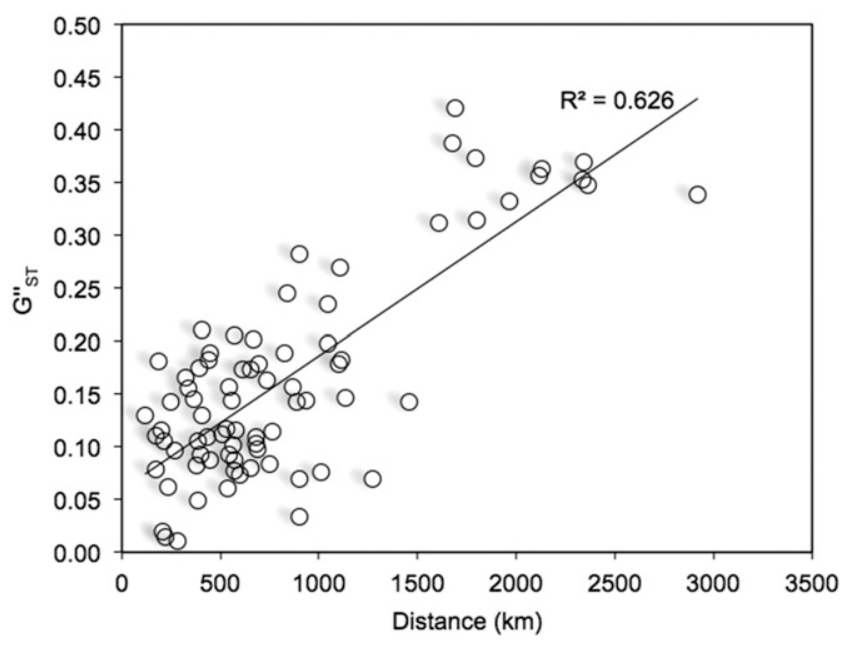

Fig. 5. Relationship of population differentiation ( $G^{\prime \prime}$ ST) with geographical distance among PST subpopulations.
Genetic differentiation of Pst mainly occurred within populations, agreeing with previous studies (Chen 2008; Lu et al. 2009; Wang et al. 2010a,b). The general consensus is that mutation and somatic recombination could generate increased levels of Pst variability (Park and Wellings 2012). Recently the Pst sexual stage was observed on barberry (Jin et al. 2010) and a very low level of Pst sexual reproduction was reported to have occurred in Shaanxi, Gansu, and Tibet (Wang et al. 2016). Ali et al. (2014b) showed heterogeneity in levels of Pst recombination in the Himalayan and nearHimalayan regions; the 71 Chinese Pst isolates used in that study originated from Longnan in Gansu Province, China (Ali, personal communication). We also demonstrated heterogeneity in Longnan, in the Himalayan Mountains, and in the southern Qinling Mountains, which might be due to admixtures as alternative hosts of Pst: Berberis spp. may serve as alternate hosts for $P s t$ sexual reproduction. However, barberry is believed not to play a role for stripe rust in the U.S. Pacific Northwest (Wang and Chen 2015).

Tibet is situated in the Qinghai-Tibet Plateau with average altitude exceeding 4,500 m, covering most of Tibet and Qinghai Province. It stretches approximately $1,000 \mathrm{~km}$ north to south and 2,500 km east to west and is surrounded by large mountain ranges. The plateau is bordered to the north by the Kunlun Mountains with average altitude $>5,500 \mathrm{~m}$, and to the east by the Hengduan Mountains with average altitude $>4,100 \mathrm{~m}$. These mountains form a natural barrier in the southwest direction between Tibet and the main Pst epidemic regions in China, preventing/minimizing Pst gene flows, as indicated by the low $N_{m}$ estimates in the present study. Pst race composition and frequency in Tibet also suggested Tibet as another center of inoculum source and virulence ( $\mathrm{Hu}$ et al. 2012), agreeing with results based on AFLP markers (Kuang 2010). The Tibet Pst population could have been experiencing considerable gene flow with Pst populations in Nepal and India via Yarlung Zangbo Canyon. Further studies are necessary to assess this possible dispersal route.

In recent years, the "metapopulation" theory advocated by Burdon and Thrall (2009) has been a predominant theory in population genetics. This theory views the "host-pathogen" system as one entire population in which host and pathogen are the two subgroups. Host varieties exert a strong directional selection pressure on rust pathogens. This may explain why the Pst population from Tibet is more or less independent of the other populations because wheat cultivars used in Tibet are different (more correctly different resistance genes) from those used in the other regions. Fewer resistance genes are present in those wheat cultivars grown in Tibet region than in the other regions (Cao et al. 2011; Han et al. 2012; Li et al. 2008, 2015; Peng et al. 2015; Zhang et al. 2012).

In summary, the Pst epidemic in the Tibet region can be considered to be independent from the epidemics occurring in the other regions, with the exception of the Xinjiang region in China. In addition, there is extensive Pst gene flow within the main wheat production

Table 5. Estimates of population differentiation $\left(\mathrm{G}^{\prime \prime}\right.$ ST) (above diagonal) and its significance (i.e., $P$ values: below diagonal), and geographical distance (i.e., value in kilometer in parenthesis) for all pairs of subpopulations within the two genetic clusters of Puccinia striiformis f. sp. tritici as determined from DAPC analysis (Jombart et al. 2010)

\begin{tabular}{|c|c|c|c|c|c|c|c|c|c|c|c|c|c|}
\hline Subpop & $\mathbf{P} 1^{\mathbf{a}}$ & $\mathbf{P 2}$ & P3 & P4 & P5 & P6 & P7 & P8 & P9 & P10 & P11 & P12 & P13 \\
\hline P1 & - & $0.062(233)^{\mathrm{c}}$ & $0.143(250)$ & $0.156(866)$ & $0.146(1,132)$ & $0.087(450)$ & $\mathbf{0 . 0 8 7}^{\mathrm{b}}(571)$ & $0.103(683)$ & 0.144 (934) & $0.111(176)$ & $0.129(406)$ & $0.144(555)$ & $0.347(2,365)$ \\
\hline $\mathbf{P 2}$ & 0.001 & - & $0.073(597)$ & $0.182(1,111)$ & $0.142(1,460)$ & $0.084(748)$ & $\mathbf{0 . 0 3 4}(900)$ & $0.076(1,011)$ & $0.07(1,275)$ & $0.02(207)$ & $0.116(577)$ & $0.093(545)$ & $0.339(2,917)$ \\
\hline P3 & 0.001 & 0.001 & - & $0.188(824)$ & $0.143(885)$ & $0.116(202)$ & $0.166(324)$ & 0.109 (435) & $0.098(687)$ & $0.092(401)$ & $0.145(364)$ & $0.077(572)$ & $0.356(2,117)$ \\
\hline P4 & 0.001 & 0.001 & 0.001 & - & $0.173(611)$ & $0.109(678)$ & $0.112(510)$ & $0.21(403)$ & $0.202(664)$ & $0.198(1,042)$ & $0.245(839)$ & $0.235(1,047)$ & $0.311(1,605)$ \\
\hline P5 & 0.001 & 0.001 & 0.001 & 0.001 & - & $0.163(737)$ & $0.205(570)$ & $0.182(442)$ & $0.102(562)$ & $0.178(1,101)$ & $0.282(899)$ & $0.269(1,107)$ & $0.421(1,687)$ \\
\hline P6 & 0.001 & 0.001 & 0.001 & 0.001 & 0.001 & - & $0.078(175)$ & $0.011(286)$ & $0.117(531)$ & $0.105(387)$ & $0.181(184)$ & $0.174(392)$ & $0.332(1,968)$ \\
\hline P7 & 0.008 & 0.097 & 0.001 & 0.001 & 0.001 & 0.015 & - & 0.129 (120) & $0.082(381)$ & $0.06(539)$ & 0.155 (337) & $0.156(545)$ & $0.314(1,802)$ \\
\hline P8 & 0.001 & 0.002 & 0.001 & 0.001 & 0.001 & 0.271 & 0.002 & - & $0.096(269)$ & $0.08(651)$ & $0.189(448)$ & $0.173(656)$ & $0.387(1,675)$ \\
\hline P9 & 0.001 & 0.014 & 0.001 & 0.001 & 0.004 & 0.001 & 0.036 & 0.01 & - & $0.07(900)$ & $0.178(698)$ & $\mathbf{0 . 1 1 4}(763)$ & $0.373(1,796)$ \\
\hline P10 & 0.001 & 0.036 & 0.001 & 0.001 & 0.001 & 0.001 & 0.021 & 0.001 & 0.011 & - & $0.105(213)$ & 0.049 (389) & $0.352(2,333)$ \\
\hline P11 & 0.001 & 0.001 & 0.001 & 0.001 & 0.001 & 0.001 & 0.001 & 0.001 & 0.001 & 0.001 & - & $0.014(223)$ & $0.363(2,130)$ \\
\hline P12 & 0.001 & 0.006 & 0.002 & 0.001 & 0.001 & 0.001 & 0.008 & 0.001 & 0.01 & 0.02 & 0.23 & - & $0.369(2,341)$ \\
\hline P13 & 0.001 & 0.001 & 0.001 & 0.001 & 0.001 & 0.001 & 0.001 & 0.001 & 0.001 & 0.001 & 0.001 & 0.001 & - \\
\hline
\end{tabular}

${ }^{a}$ P1 (Tianshui), P2 (Pingliang), P3 (Longnan), P4 (Aba), P5 (Liangshan), P6 (Guangyuan), P7 (Mianyang), P8 (Chengdu), P9 (Yibin), P10 (Baoji), P11 (Hanzhong), P12 (Ankang) subpopulations from Cluster 1; P13 (Linzhi) subpopulation from Cluster 2.

b Values in bold indicate no significant difference at $P=0.001$.

${ }^{\mathrm{c}}$ Geographical distance in kilometer in the parentheses was estimated using Google Earth. 
area in China. Further research is necessary to study the distribution of Pst alternative host Berberis spp. and their roles in Pst epidemiology and genetic diversity.

\section{Acknowledgments}

This work was supported by the National Key Basic Research Program of China (2013CB127704), the National Natural Science Foundation of China (31471731 and 31371884), the Program for Innovative Research in Northwest A\&F University (X2015021), and partially supported by the 111 Project from Education Ministry of China (B07049). We pay a special thanks to Dr. Pierre Gladieux (Ecologie Systematique Evolution, Univ. Paris-Sud., France) and Dr. Sajid Ali (Institute of Biotechnology and Genetic Engineering, The University of Agriculture, Pakistan) for their valuable suggestions.

\section{Literature Cited}

Agapow, P. M., and Burt, A. 2001. Indices of multilocus linkage disequilibrium. Mol. Ecol. Notes 1:101-102.

Ali, S., Gladieux, P., Leconte, M., Gautier, A., Justesen, A. F., Hovmøller, M. S., Enjalbert, J., and de Vallavieille-Pope, C. 2014a. Origin, migration routes and worldwide population genetic structure of the wheat yellow rust pathogen Puccinia striiformis f. sp. tritici. PLoS Pathog 10:e1003903.

Ali, S., Gladieux, P., Rahman, H., Saqib, M. S., Fiaz, M., Ahmad, H., Leconte, M., Gautier, A., Justesen, A. F., Hovmøller, M. S., Enjalbert, J., and de VallavieillePope, C. 2014b. Inferring the contribution of sexual reproduction, migration and off-season survival to the temporal maintenance of microbial populations: a case study on the wheat fungal pathogen. Mol. Ecol. 23:603-617.

Burdon, J. J., and Thrall, P. H. 2009. Co-evolution of plants and their pathogens in natural habitats. Science 324:755-756.

Cao, S. Q., Zhang, B., Li, M. J., Xu, S. C., Luo, H. S., Jin, S. L., Jia, Q. Z., Huang, J., and Shang, X. W. 2011. Postulation of stripe rust resistance genes and analysis of adult resistance in 50 wheat varieties (lines) in Gansu Province. Acta Agron. Sin. 37:1360-1371.

Chen, C. Q. 2008. Molecular population genetic structure of Puccinia striiformis f. sp. tritici in China. Ph.D. Dissertation, Northwest A\&F University, Yangling, China (in Chinese with English abstract)

Chen, C. Q., Zheng, W. M., Buchenauer, H., Huang, L. L., Lu, N. H., and Kang, Z. S. 2009. Isolation of microsatellite loci from expressed sequence tag library of Puccinia striiformis f. sp. tritici. Mol. Ecol. Notes 9:236-238.

Chen, X. M. 2005. Epidemiology and control of stripe rust [Puccinia striiformis f. sp. tritici] on wheat. Can. J. Plant Pathol. 27:314-337.

Chen, X. M., Line, R. F., and Leung, H. 1993. Relationship between virulence variation and DNA polymorphism in Puccinia striiformis. Phytopathology 83:1489-1497.

Cheng, P., and Chen, X. M. 2014. Virulence and molecular analyses support asexual reproduction of Puccinia striiformis f. sp. tritici in the U.S. Pacific Northwest. Phytopathology 104:1208-1220

Culley, T. M., Wallace, L. E., Genger-Nowak, K. M., and Crawford, D. J. 2002. Comparison of two methods of calculating GST, a genetic measure of population differentiation. Am. J. Bot. 89:460-465.

Dilmaghani, A., Gladieux, P., Gout, L., Giraud, T., Brunner, P. C., Stachowiak, A., Balesdent, M. H., and Rouxel, T. 2012. Migration patterns and changes in population biology associated with the worldwide spread of the oilseed rape pathogen Leptosphaeria maculans. Mol. Ecol. 21:2519-2533.

Duan, X., Tellier, A., Wan, A., Leconte, M., de Vallavieille-Pope, C., and Enjalbert, J. 2010. Puccinia striiformis $\mathrm{f}$. sp. tritici presents high diversity and recombination in the over-summering zone of Gansu, China. Mycologia 102:44-53.

Enjalbert, J., Duan, X., Giraud, T., Vautrin, D., de Vallavieille-Pope, C., and Solignac, M. 2002. Isolation of twelve microsatellite loci, using an enrichment protocol in the phytopathogenic fungus $P$. striiformis f. sp. tritici. Mol. Ecol. Notes 2:563-565

Enjalbert, J., Duan, X., Leconte, M., Hovmøller, M. S., and de Vallavieille-Pope, C. 2005. Genetic evidence of local adaptation of wheat yellow rust (Puccinia striiformis f. sp. tritici) within France. Mol. Ecol. 14:2065-2073.

Evanno, G., Regnaut, S., and Goudet, J. 2005. Detecting the number of clusters of individuals using the software STRUCTURE: a simulation study. Mol. Ecol. 14:2611-2620.

Falush, D., Stephens, M., and Pritchard, J. K. 2003. Inference of population structure using multilocus genotype data: Linked loci and correlated allele frequencies. Genetics 164:1567-1587.

Han, D. J., Zhang, P. Y., Wang, Q. L., Zeng, Q. D., Wu, J. H., Zhou, X. L., Wang, X. J., Huang, L. L., and Kang, Z. S. 2012. Identification and evaluation of resistance to stripe rust in 1980 wheat landraces and abroad germplasm. Sci. Agric. Sin. 45:5013-5023.

Hedrick, P. W. 2005. A standardized genetic differentiation measure. Evolution 59:1633-1638

Hovmøller, M. S., Justesen, A. F., and Brown, J. K. M. 2002. Clonality and longdistance migration of Puccinia striiformis f.sp. tritici in north-west Europe. Eur. J. Plant Pathol. 51:24-32

Hovmøller, M. S., Sørensen, C. K., Walter, S., and Justesen, A. F. 2011. Diversity of Puccinia striiformis f.sp. tritici on cereals and grasses. Annu. Rev. Phytopathol. 49:197-217
Hovmøller, M. S., Walter, S., and Justesen, A. F. 2010. Escalating threat of wheat rusts. Science 329:369.

Hu, X. P., Li, J. J., Wang, Y., Wang, B. T., Li, Q., Kang, Z. S., Yang, M. N., Peng, Y. L., Liu, T. G., Chen, W. Q., and Xu, X. M. 2012. Race composition of Puccinia striiformis f. sp. tritici in Tibet, China. Plant Dis. 96:1615-1620.

Hu, X. P., Yang, Z. W., Li, Z. Q., Deng, Z. Y., Chen, H. W., and Ke, C. H. 2000. Factors analysis affected the epidemics of wheat stripe rust in Hanzhong district Shaanxi province. Acta Agr. Boreali-occidentalis Sin. 9:36-38 (in Chinese with English abstract).

Jakobsson, M., and Rosenberg, N. A. 2007. CLUMPP: a cluster matching and permutation program for dealing with label switching and multimodality in analysis of population structure. Bioinformatics 23:1801-1806.

Jin, Y., Szabo, L. J., and Carson, M. 2010. Century-old mystery of Puccinia striiformis life history solved with the identification of Berberris as an alternate host. Phytopathology 100:432-435.

Jombart, T. 2008. adegenet: a R package for the multivariate analysis of genetic markers. Bioinformatics 24:1403-1405.

Jombart, T., Devillard, S., and Balloux, F. 2010. Discriminant analysis of principal components: a new method for the analysis of genetically structured populations. BMC Genet. 11:94.

Kuang, W. J. 2010. Population diversity of Puccinia striiformis in Tibet. Master Dissertation, Sichuan Agricultural University, Yaan, China (in Chinese with English abstract).

Li, F. Q., Han, D. J., Wie, G. R., Zeng, Q. D., Huang, L. L., and Kang, Z. S. 2008. Molecular detection of stripe rust resistant genes in 126 winter wheat varieties from the Huanghuai wheat region. Sci. Agric. Sin. 41:3060-3069.

Li, M. Z., Li, Q., Cao, K. X., Shen, X. X., Fan, Y., Wang, Y., and Wang, B. T. 2015. Molecular detection of stripe rust resistance genes in 115 whea varieties (lines) from Shaanxi Province. Acta Phytopathol. Sin. 45:632-640.

Li, Z. Q., and Liu, H. W. 1957. Preliminary studies on the trend of occurrence an development of the stripe rust of wheat (Puccinia glumarum (Sch.) Eriks. and Henn.) in provinces Shenst, Kansu, and Chinghai. J. Northwest Agr. Coll. 1:34-46 (in Chinese with English abstract).

Li, Z. Q., and Zeng, S. M. 2002. Pages 1-11 in: Wheat rust in China. China Agricultural Press, Beijing (in Chinese).

Lu, N. H., Wang, J. F., Chen, X. M., Zhan, G. M., Chen, C. Q., Huang, L. L., and Kang, Z. S. 2011. Spatial genetic diversity and interregional spread of $P$. striiformis f. sp. tritici in Northwest China. Eur. J. Plant Pathol. 131:685-693.

Lu, N. H., Wang, J. F., Zhan, G. M., Huang, L. L., and Kang, Z. S. 2009. SSR analysis of population genetic diversity of Puccinia striiformis $\mathrm{f}$. sp. tritici in different altitude regions of Longnan, Gansu. Mycosystema 28:496-503.

Mboup, M., Leconte, M., Gautier, A., Wan, A. M., Chen, W., de Vallavieille-Pope, C., and Enjalbert, J. 2009. Evidence of genetic recombination in wheat yellow rust populatiions of a Chinese oversummering area. Fungal Genet. Biol. 46:299-307.

Meirmans, P. G., and Hedrick, P. W. 2011. Assessing population structure: $\mathrm{F}_{\mathrm{ST}}$ and related measures. Mol. Ecol. Resour. 11:5-18.

Nei, M. 1973. Analysis of gene diversity in subdivided populations. Proc. Natl. Acad. Sci. USA 70:3321-3323.

Nei, M. 1978. Estimation of average heterozygosity and genetic distance from a small number of individuals. Genetics 89:583-590.

Park, R. F., and Wellings, C. R. 2012. Somatic hybridization in the uredinales. Annu. Rev. Phytopathol. 50:219-239.

Peng, Y. L., Yang, M. N., Dan, B., and Ci, Z. G. 2015. Molecular detection of stripe rust resistance genes in 41 wheat varieties from Tibet. Acta Phytopathol. Sin. 45 : $211-215$

Pritchard, J. K., Stephens, M., and Donnelly, P. 2000. Inference of population structure using multilocus genotype data. Genetics 155:945-959.

Shan, W. X., Chen, S. Y., Kang, Z. S., Wu, L. R., and Li, Z. Q. 1998. Genetic diversity in Puccinia striiformis Westend. f. sp. tritici revealed by pathogen genome-specific repetitive sequence. Can. J. Bot. 76:587-595.

Shen, L., Luo, L. M., Chen, W. Q., Zhao, Z. M., and Wang, J. J. 2008. Epidemic zones and dispersal routes of wheat stripe rust caused by Puccinia striiformis West. in Sichuan. Acta Phytophylac. Sin. 35:220-226 (in Chinese with English abstract).

Steele, K. A., Humphreys, E., Wellings, C. R., and Dickinson, M. J. 2001. Support for a stepwise mutation model for pathogen evolution in Australasian Puccinia striiformis f. sp. tritici by use of molecular markers. Plant Pathol. 50:174-180.

Szpiech, Z. A., Jakobsson, M., and Rosenberg, N. A. 2008. ADZE: a rarefaction approach for counting alleles private to combinations of populations. Bioinformatics 24:2498-2504

Tibayrenc, M., and Ayala, F. J. 2002. The clonal theory of parasitic protozoa: 12 years on. Trends Parasitol. 18:405-410.

Tibayrenc, M., and Ayala, F. J. 2012. Reproductive clonality of pathogens: A perspective on pathogenic viruses, bacteria, fungi, and parasitic protozoa. Proc. Natl. Acad. Sci. USA 109:E3305-E3313.

Wan, A. M., Zhao, Z. H., Chen, X. M., He, Z. H., Jin, S. L., Jia, Q. Z., Yao, G., Yang, J. X., Wang, B. T., Li, G. B., Bi, Y. Q., and Yuan, Z. Y. 2004. Wheat stripe rust epidemic and virulence of Puccinia striiformis $\mathrm{f}$. sp. tritici in China in 2002. Plant Dis. 88:896-904.

Wang, H. G., Yang, X. B., and Ma, Z. H. 2010a. Long-distance spore transport of wheat stripe rust pathogen from Sichuan, Yunnan, and Guizhou in Southwestern China. Plant Dis. 94:873-880. 
Wang, J. F., Cheng, C. Q., Lu, N. H., Peng, Y. L., Zhan, G. M., Huang, L. L., and Kang, Z. S. 2010b. SSR analysis of population genetic diversity of Puccinia striiformis f. sp. tritici in Sichuan Province, China. Mycosystema 29:206-213 (In Chinese with English abstract.)

Wang, M. N., and Chen, X. M. 2015. Barberry does not function as an alternate host for Puccinia striiformis f. sp. tritici in the US Pacific Northwest due to teliospore degradation and barberry phenology. Plant Dis. 99:1500-1506.

Wang, Z. Y., Zhao, J., Chen, X. M., Peng, Y. L., Ji, J. J., Zhao, S. L., Lv, Y. J., Huang, L. L., and Kang, Z. S. 2016. Virulence variations of Puccinia striiformis f. sp. tritici isolates collected from Berberis spp. in China. Plant Dis. 100:131-138.

Wellings, C. R. 2007. Puccinia striiformis in Australian: A review of the incursion, evolution and adaptation of stripe rust in the period 1979-2006. Aust. J. Agric. Res. 58:567-575.

Wright, S. 1951. The genetical structure of population. Ann. Eugen. 15:323-354.

Wu, L. R., and Niu, Y. C. 2000. Strategies of sustainable control of wheat stripe rust in China. Sci. Agric. Sin. 33:1-7 (in Chinese with English abstract).

Xie, S. X., Chen, Y. L., Chen, W. Q., Wang, K. N., Ding, X. P., He, X. L., Pu, J. C., Qi, S. W., Ou, Y., and Du, D. M. 1988. Studies on the epidemiology of wheat stripe rust (Puccinia striiformis West.) in Abazhou, Sichuan province. Acta Phytophylac. Sin. 15:85-91 (in Chinese with English abstract).

Xie, S. X., Chen, Y. L., Li, H. Y., Lin, X. L., Sun, Y. H., Wang, D. S., and Zeng, D. X. 1986. Studies on the epidemiology of stripe rust of wheat in Mian-Yang area, Sichuan province. Acta Phytophylac. Sin. 13:31-38 (in Chinese with English abstract).
Yeh, F. C., Yang, R., and Boyle, T. 1999. POPGENE version 1.32: Microsoft windows-based freeware for population genetic analysis, a quick user guide. University of Alberta, Center for International Forestry Research, Alberta, Canada.

Zeng, S. M., and Luo, Y. 2006. Long-distance spread and interregional epidemics of wheat stripe rust in China. Plant Dis. 90:980-988.

Zeng, S. M., and Luo, Y. 2008. Systems analysis of wheat stripe rust epidemics in China. Eur. J. Plant Pathol. 121:425-438.

Zhan, G., Wang, F., Wan, C., Han, Q., Huang, L., and Kang, Z. 2016. Virulence and molecular diversity of the Puccinia strifformis f. sp. tritici population in Xinjiang in relation to other regions of western China. Plant Dis. 100:99-107.

Zhan, J., Kema, G. H. J., Waalwijk, C., and McDonald, B. A. 2002. Distribution of mating type alleles in the wheat pathogen Mycosphaerella graminicola over spatial scales from lesions to continent. Fung. Genet. Biol. 36:128-136.

Zhang, Z. Y., Ji, H. L., Shen, L., Xu, S. C., Ni, J. Y., and Peng, Y. L. 2012 Postulation of resistance genes and evaluation of adult resistance to stripe rust in 58 cultivars from Sichuan. Acta Phytophylac. Sin. 39:13-23.

Zhao, J., Wang, L., Wang, Z. Y., Chen, X. M., Zhang, H. C., Yao, J. N., Zhan, G. M., Chen, W., Huang, L. L., and Kang, Z. S. 2013. Identification of eighteen Barberis species as alternate hosts of Puccinia striiformis f. sp. tritici and virulence variation in the pathogen isolates from natural infection of barberry plants in China. Phytopathology 103:927-934.

Zheng, W. M., Chen, S. Y., Kang, Z. S., Wang, Y., Wu, L. R., and Li, Z. Q. 2005 DNA fingerprinting of natural population of Puccinia striiformis f. sp. tritici in Tianshui area. Mycosystema 24:199-206 (in Chinese with English abstract). 